Bangladesh J. Zool. 46(1): 71-80, 2018

\title{
INTENSIVE POLYCULTURE OF COMMON CARP (CYPRINUS CARPIO), MIRROR CARP (CYPRINUS CARPIO CARPIO), SILVER CARP (HYPOPHTHALMICHTHYS MOLITRIX) AND GRASS CARP (CTENOPHARYNGODON IDELLA) AT DIFFERENT STOCKING DENSITIES
}

\author{
Dulon Roy ${ }^{*}$, Zavyalov Aleksandar Petrobich, Blacob Balentin Aleksebich and \\ Gulshan Ara Latifa ${ }^{2}$ \\ Department of Apiculture and Aquaculture, Russian State Agricultural University, \\ Moscow, Russia
}

\begin{abstract}
An experiment was carried out for 6 months on rearing of common carp, mirror carp, grass carp and silver carp under polyculture system at different stocking densities in cemented tanks $(5-7 \mathrm{~m}$ in diameter and water depth 1.0 $1.5 \mathrm{~m}$ ). Observations were made on fish growth in terms of monthly and per day weight gain. Grass carp attained the maximum weight $686 \pm 17,720 \pm 16.5$ and $765 \pm 9.6$ in three tanks, respectively. Weight gained followed by silver carp as 680 $\pm 10 \mathrm{~g}, 680 \pm 12.6 \mathrm{~g}$ and $701 \pm 9.2 \mathrm{~g}$ in tank 1 , tank 2 and tank 3 , respectively. The common carp gained its average maximum weight $525 \pm 10.7 \mathrm{~g}$ in tank3 and the mirror carp also attained its maximum weight $500 \pm 12.2 \mathrm{~g}$ in same tank. In common carp the maximum average daily weight gain $(3.2 \pm 0.1 \mathrm{~g})$ was in the month of December and lowest was (1.92 $\pm 0.2 \mathrm{~g})$ in the month of August in tank 3 . In mirror carp the maximum average daily weight gain $(3.03 \pm 0.09 \mathrm{~g})$ was in the month of September and lowest $(1.41 \pm 0.07 \mathrm{~g})$ in the month of July in tank 3 and tank 2 , respectively. In grass carp the maximum average daily weight gain ( $4.24 \pm 0.17 \mathrm{~g})$ was in the month of August and lowest $(2.72 \pm 0.07 \mathrm{~g}$ ) in the month of July in tank 3 and tank 1, respectively. Among silver carp the maximum average daily weight gain $(4.45 \pm 0.01 \mathrm{~g})$ recorded in the month of October and lowest was $(2.61 \pm 0.11 \mathrm{~g})$ in the month of July in tank 1 . The specific growth rate (SGR) was $1.23 \pm 0.64$ to $1.33 \pm 0.83$ in common carp, $1.27 \pm 0.9$ to $1.34 \pm 0.8$ in mirror carp, $1.36 \pm 0.86$ to $1.55 \pm 1.13$ in grass carp and $1.41 \pm 0.83$ to $1.52 \pm$ 1.09 in silver carp in different culture treatments.
\end{abstract}

Key words: Exotic carp, intensive, polyculture, growth rate

\section{INTRODUCTION}

The culture of fish in tanks is a good alternative way if sufficient water or land is not available and the environment is not favorable for culture. Exotic carps (common carp, mirror carp, silver carp and grass carp) grow well in intensive culture system. Intensive tank culture ensures several advantages.

During intensive tank culture of fish, tank manages the fish stock; regulates a high degree of environmental parameters e.g. water temperature, dissolved oxygen, dissolved $\mathrm{CO}_{2}, \mathrm{pH}$ and alkalinity etc. Tank improves the uniformity of the culture environment and allows a wide range of rotational velocities to

*Author for correspondence: <dulonroy@gmail.com>. 'Department of Zoology, Jagannath University, Dhaka-1000, Bangladesh. ${ }^{2}$ Department of Zoology, University of Dhaka, Dhaka-1000, Bangladesh.

(C) 2018 Zoological Society of Bangladesh DOI: http://dx.doi.org/10.3329/bjz.v46i1.37628 
optimize fish health and condition. Tank culture also has some disadvantages due to limited access to natural foods. The cost of pumping water and aeration increases the total production cost.

In Asia, carp culture grew on 12\% annually during the last two decades (Dey et al. 2005). Carp contributes more than $70 \%$ of the inland aquaculture production in Asia and the world and considered as the major provider of fish protein through aquaculture (Acosta and Gupta 2005). With the increase in fish demand trend, measures have developed to culture fish more intensively to enhance the present level of fish production (Hussein 2012).

In China, polyculture of grass carp with other species of different feeding habits is traditionally practiced, whereas grass carp consumes low value, vegetative waste and increase natural food production in the pond by nutrient recycling and fecal production (Yang et al. 1990, Li and Mathias 1994). In Nepal, pond fish culture is mostly conducted in the southern subtropical region, where pond water temperature falls between 15 and $20^{\circ} \mathrm{C}$ during winter period from mid December to mid-February (Shrestha 1999).

To develop the methods and techniques of tank fish culture, to assess the growth of these exotic carps in tank polyculture system for their profitability and economic viability attempt was made.

\section{MATERIAL AND METHODS}

The experiment was carried out at Department of Aquaculture, Russian State Agricultural University, Moscow, Russia. Management of fish polycuture in tanks includes successive stages from tank preparation to final harvesting of fish.

Tank preparation: Three tanks with $5-7 \mathrm{~m}$ in diameter and water depth 1 $1.5 \mathrm{~m}$ were selected for demonstrating this study and observation of growth performance of fishes under carp polyculture. Recommended tank diameter to depth ratios vary from $5: 1$ to $10: 1$ (Chenoweth et al. 1973). The selected tanks were prepared before stocking the fish fry.

Species selection: Selection of compatible fast growing species was of vital importance in maximizing fish production. This was also considered that the species grows fast without accumulation of natural food. A combination of four species, viz. common carp (Cyprinus carpio), mirror carp (Cyprinus carpio carpio), grass carp (Ctenopharyngodon idella) and silver carp (Hypophthalmicthys molitrix). Of these common carp and mirror carp are bottom feeder, grass carp column feeder and silver carp is surface feeder. 
Stocking density: Fishes were stocked in three tanks. Tank 1 (T1), Tank 2 (T2) and Tank 3 (T3) by completely randomized design (CRD).

Table 1. Stocking densities of different fishes in three different tanks (1 - 3)

\begin{tabular}{lccc}
\hline \multirow{2}{*}{ Fish } & \multicolumn{3}{c}{ Stoking densities of different fish species in three different treatments } \\
\cline { 2 - 4 } species & $\mathrm{T} 1$ & $\mathrm{~T} 2$ & $\mathrm{~T} 3$ \\
\hline Common crap & 50 & 50 & 30 \\
Mirror carp & 50 & 50 & 30 \\
Grass carp & 20 & 25 & 20 \\
Silver carp & 30 & 25 & 20 \\
Total & 150 & 150 & 100 \\
\hline
\end{tabular}

Feeding fishes: After stocking fingerlings supplementary food (Table 2) were applied 2 - 3 times in a day according to the $5-7 \%$ of the body weight.

Table 2. Ratios of the ingredients of supplementary food

\begin{tabular}{lc}
\hline Ingredients & Percentage \\
Fish meal & 30 \\
Mastered oil cake & 25 \\
Soyabean cake & 20 \\
Broken rice & 20 \\
Wheat bran & 5 \\
\hline
\end{tabular}

Sampling of fish: Sampling of fish was done in every 15 days to check the health condition, growth rate and mortality of the fishes. Periodic sampling of fish was done once at least in a month.

Water quality parameters: Physico-chemical parameters such as water temperature $\left({ }^{\circ} \mathrm{C}\right)$, dissolved oxygen $(\mathrm{mg} / \mathrm{l}), \mathrm{pH}$ was measured by thermometer, DO meter (DO8401) and $\mathrm{pH}$ meter (pH 004), respectively.

Harvesting: Final harvesting of fish was done after 6 months of stocking in tanks when the carrying capacity of tank was saturated.

Statistical analysis: Simple arithmetical tools like average, range, percentage etc. were used to tabulate the results. For analysis of treatment effects of fish production and separation of treatments means by DMRT were performed as per methods outlined in Gomez and Gomez (1985). Specific growth rate determined by $\mathrm{SGR}=100\left(\ln . \mathrm{W}_{2}-\ln . \mathrm{W}_{1}\right) /$ days and average daily gain determined by $\mathrm{ADG}=$ (Final weight W2 - initial weight W1)age (days). 


\section{RESULTS AND DISCUSSION}

The optimum fish production depends on the physico-chemical qualities of water. The water quality parameters that were recorded during the study period are provided in Table 3.

Table 3. Average Physicochemical parameters in three different treatments (rearing tanks)

\begin{tabular}{ccccc}
\hline \multirow{2}{*}{$\begin{array}{c}\text { Treatments } \\
(\mathrm{T}=\text { Tank })\end{array}$} & $\begin{array}{c}\text { No. of } \\
\text { estimation }\end{array}$ & \multicolumn{2}{c}{ Physicochemical parameters } \\
\cline { 3 - 5 } & 24 & $\begin{array}{c}\text { Water } \\
\text { temperature }\left({ }^{\circ} \mathrm{C}\right)\end{array}$ & $\mathrm{pH}$ & $\begin{array}{c}\text { Dissolved oxygen } \\
(\mathrm{mg} / \mathrm{l})\end{array}$ \\
\hline $\mathrm{T} 1$ & 24 & $27.4 \pm 0.8$ & $6.93 \pm 0.36$ & $6.91 \pm 0.42$ \\
$\mathrm{~T} 2$ & 24 & $27.2 \pm 0.98$ & $7.25 \pm 0.33$ & $7.35 \pm 0.31$ \\
$\mathrm{~T} 3$ & $27.8 \pm 0.75$ & $7.33 \pm 0.31$ & $7.74 \pm 0.55$ \\
\hline
\end{tabular}

The values of water quality parameters were within the acceptable ranges that regulate this intensive culture system strongly. The water temperature was almost same, $\mathrm{pH}$ value ranged from $6.93 \pm 0.36$ and $7.33 \pm 0.31$ and dissolved oxygen were $6.91 \pm 0.42$ and $7.74 \pm 0.55 \mathrm{mg} / \mathrm{l}$.

Observations were made on fish growth performances in terms of monthly weight gain and per day weight gain. The average cumulative weight gain (g) is presented in Table 4 and the average per day weight gain (g) with the specific growth rate (SGR) provided in Table 5.

All the four species attained an average maximum weight at the last month of the study period (Table 4) in three different tanks. Grass carp attained the maximum weight $686 \pm 17,720 \pm 16.5$ and $765 \pm 9.6 \mathrm{~g}$ in three tanks, respectively. Silver carp also followed by the grass carp that gained its weight $680 \pm 10,680 \pm 12.6$ and $701 \pm 9.2 \mathrm{~g}$ in $\mathrm{T} 1, \mathrm{~T} 2$ and $\mathrm{T} 3$, respectively. The common carp gained their average maximum weight $525 \pm 10.7 \mathrm{~g}$ in $\mathrm{T} 3$ and the mirror carp also attained their maximum weight $500 \pm 12.2 \mathrm{~g}$ in same tank where the stocking density was comparatively low.

Due to availability of the supplementary food the fishes increased in body weight enormously. In common carp the maximum average and daily weight gain $(3.2 \pm 0.1 \mathrm{~g})$ was in the month of December and lowest was (1.92 $\pm 0.2 \mathrm{~g})$ in the month of August in T3. In mirror carp the maximum average daily weight gain $(3.03 \pm 0.09 \mathrm{~g})$ was in the month of September and lowest was $(1.41 \pm 0.07$ g) in the month of July in T3 and T2, respectively. In grass carp the maximum average daily weight gain (4.24 $\pm 0.17 \mathrm{~g})$ was in the month of August and lowest was $(2.72 \pm 0.07 \mathrm{~g})$ in the month of July in T3 and T1, respectively. In silver carp the maximum average daily weight gain $(4.45 \pm 0.01 \mathrm{~g})$ was in the month of 


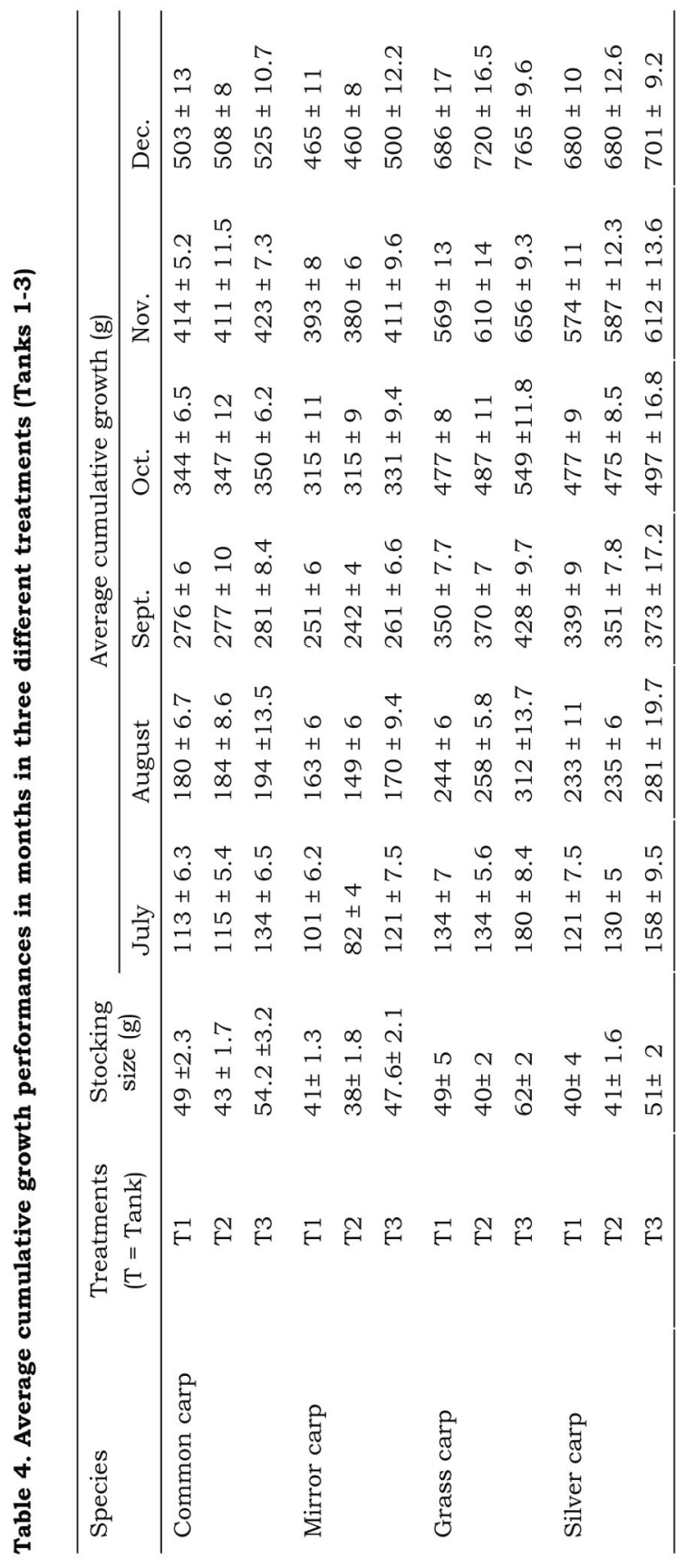




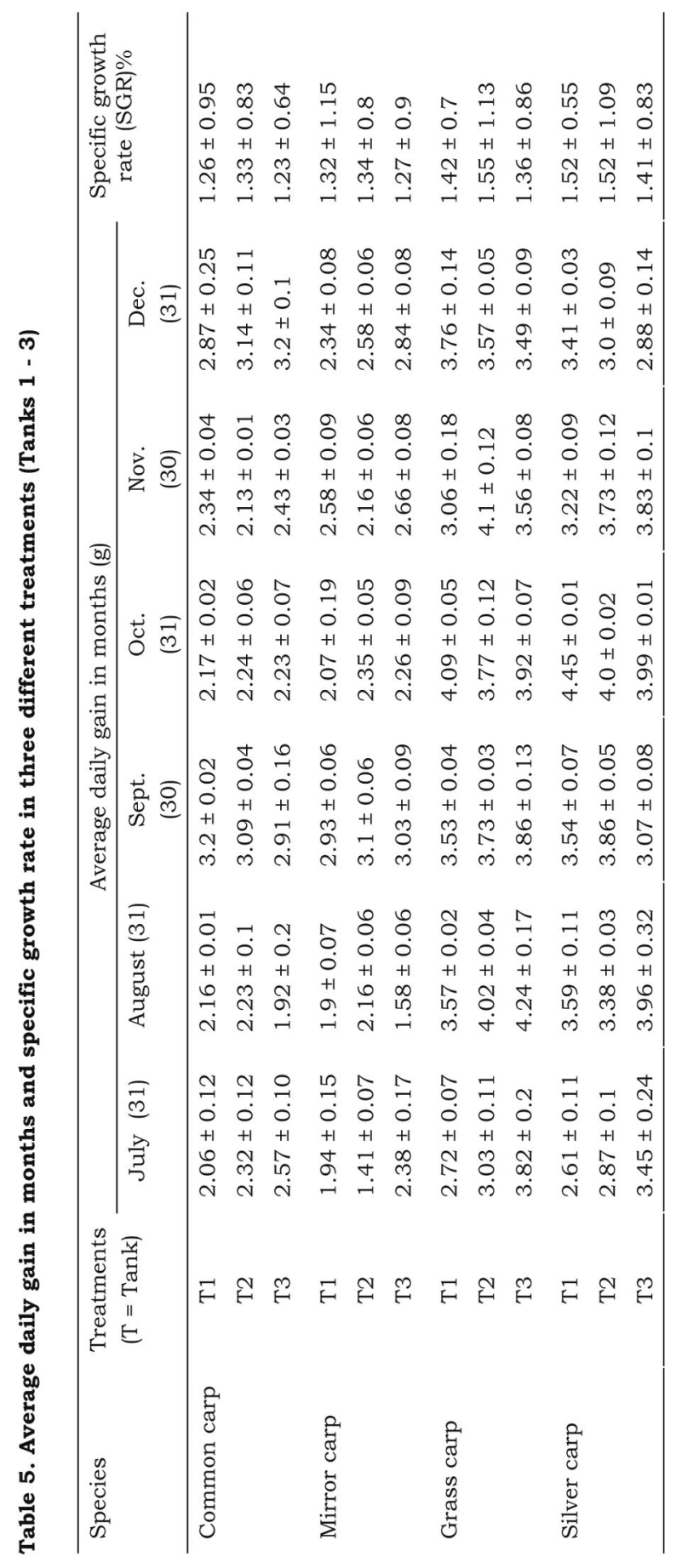




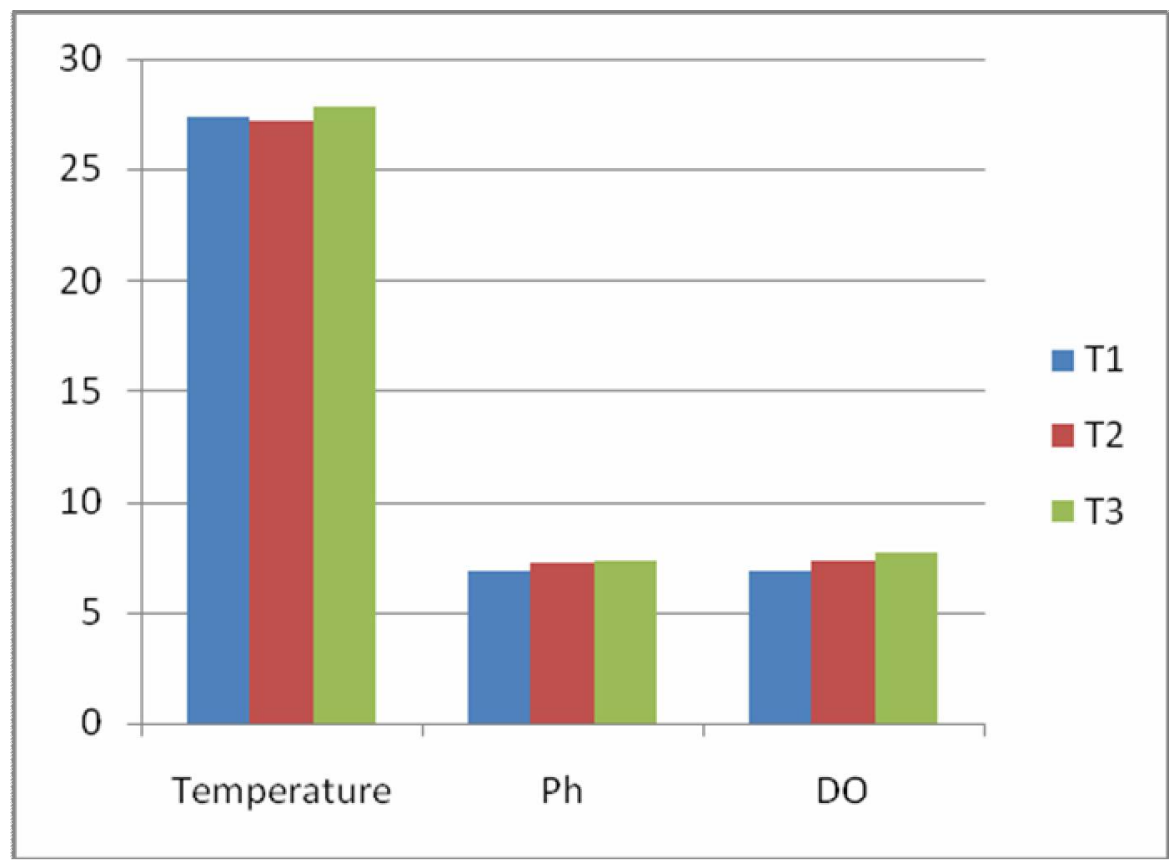

Fig. 1. Physicochemical parameters in three different treatments.

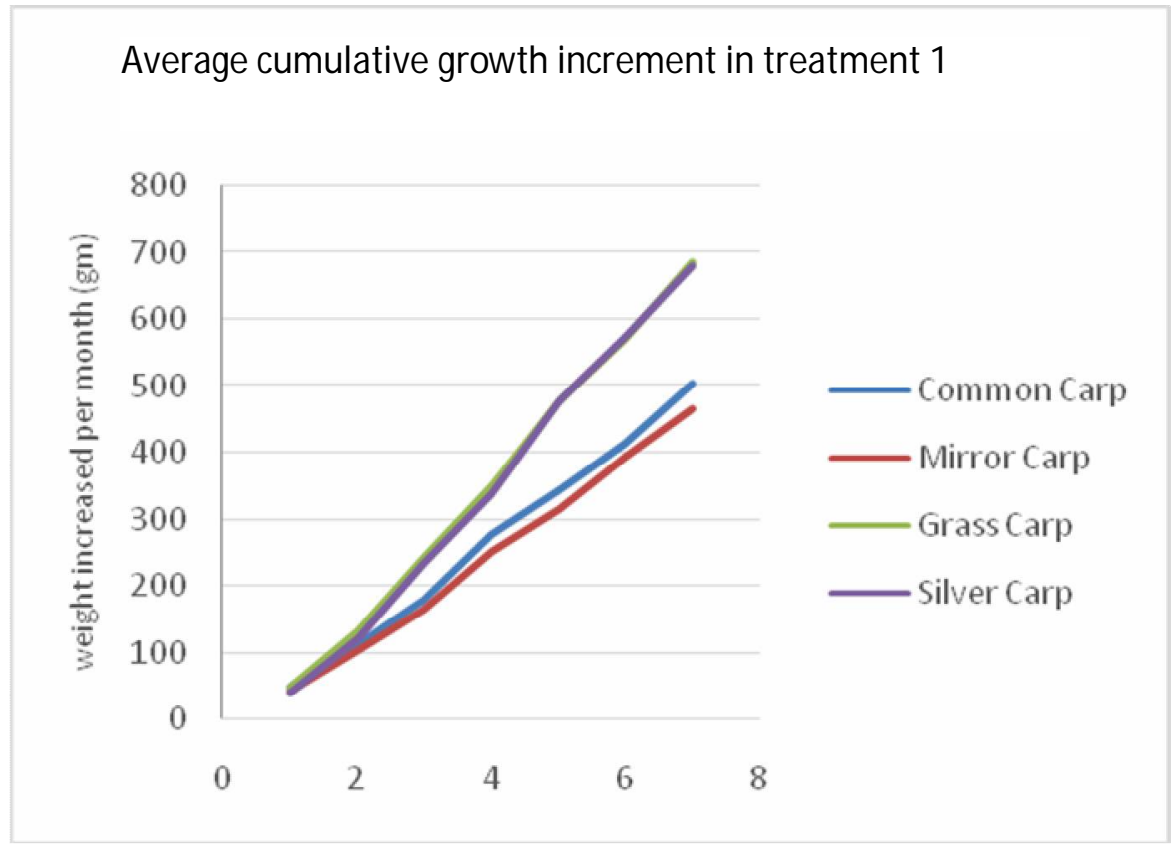

Fig. 2. Average cumulative growth increment of fishes in T1. 


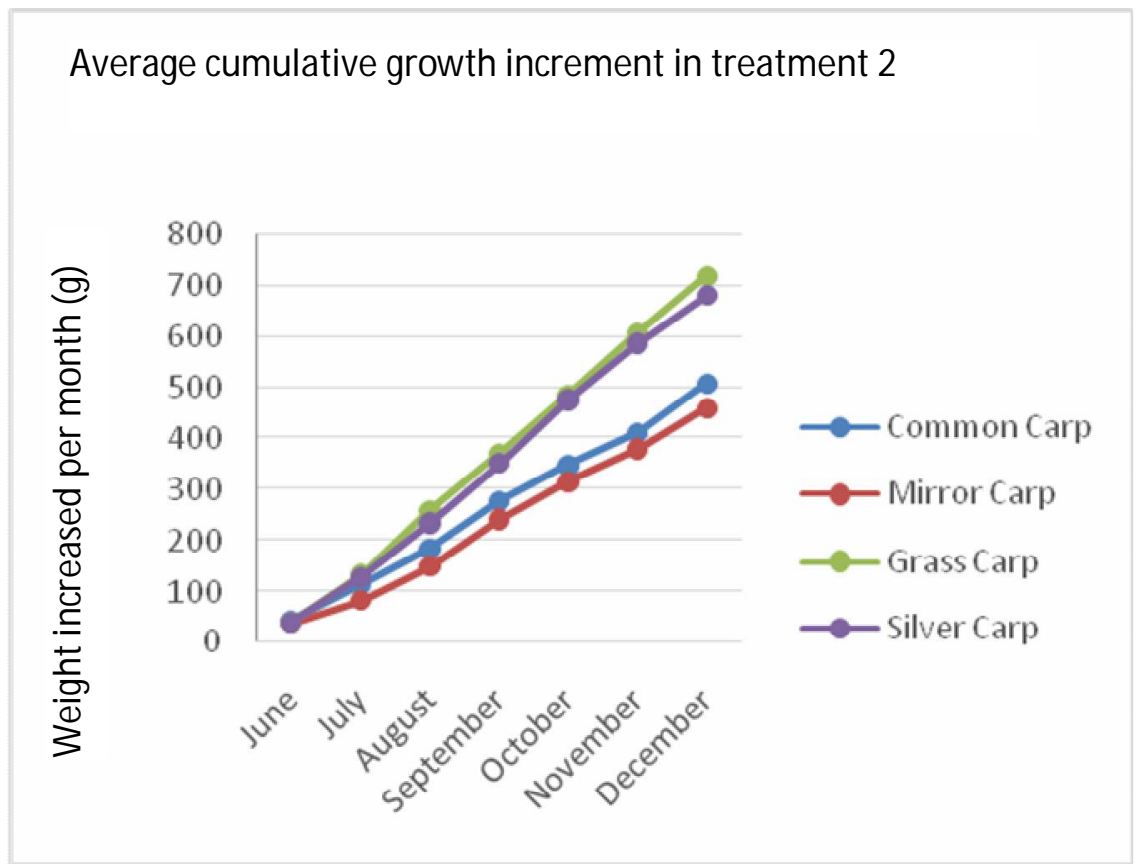

Fig. 3. Average cumulative growth increment of fishes in Treatment 2.

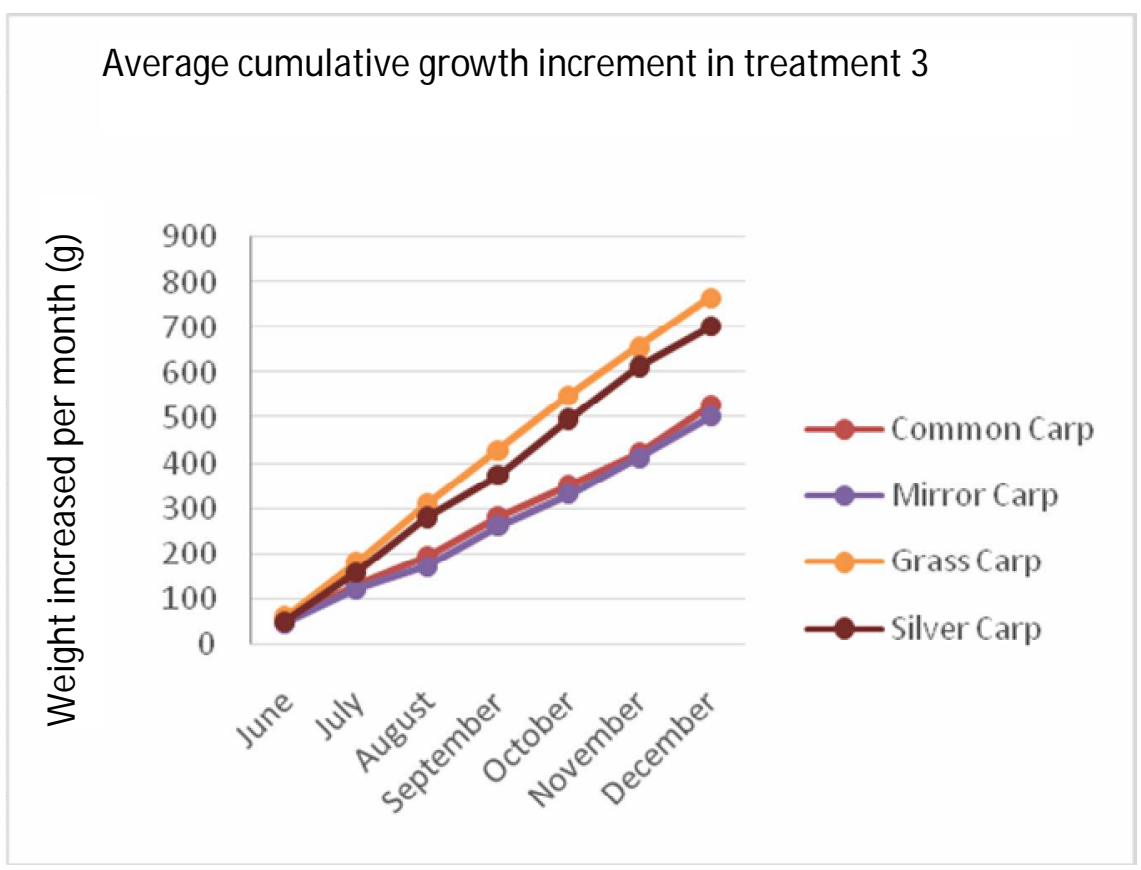

Fig. 4. Average cumulative growth increment of fishes in Treatment 3. 
October and lowest was $(2.61 \pm 0.11 \mathrm{~g})$ in the month of July in T1. The values of SGR of different fishes in different tanks summarized in Table 5. The specific growth rate (SGR) $1.23 \pm 0.64$ to $1.33 \pm 0.83$ in common carp, $1.27 \pm 0.9$ to 1.34 \pm 0.8 in mirror carp, $1.36 \pm 0.86$ to $1.55 \pm 1.13$ in grass carp and $1.41 \pm 0.83$ to $1.52 \pm 1.09$ in silver carp in different culture treatments.

The growth rate of all fish species in all variants of the experiment strongly depended on the feeding rate $(r=+0.71-0.98)$. With the increase in the stocking density of fish, the actual feeding rate decreased, and the efficiency of feed utilization increased. The effectiveness of the use of organic and mineral fertilizers directly depended on the stocking density of fish. As the average weight of fish increased, the proportion of natural food such as phyto- and zooplankton decreased in the composition.

The growth rate of fishes showed a difference with the months. In this intensive tank culture due to short of natural food the fishes were feed actively and gained their weight very quickly. Davis et al. (1983) observed that slow growth of fishes due to less feeding activity during fish growth study. Observations made on the three tanks clearly indicated that grass carp exhibited better growth than other species. But the growth of silver carp also followed by the grass carp. Jhingran (1982) reported the superiority of growth performances of silver carp. The growth rate and gained weight of common carp and mirror carp were approximately similar. In the water quality parameter, the recorded water temperature $(27.2 \pm 0.98$ to $27.8 \pm 0.75)$ was favorable for active growth and feeding of fishes because water temperature affects the feeding pattern and growth of fish. The range of $\mathrm{pH}$ and dissolved oxygen were also in normal condition that affected the growth of the fishes positively.

\section{CONCLUSION}

Growth rate of these exotic carps in intensive culture system was higher. The productivity, growth and survivability of the fishes in the tank environment were notable. Intensive culture of fishes in tanks achieved proper water circulation, which prevented low oxygen regions. Higher oxygen levels were also maintained, which improved fish health, growth rates, and feed conversion ratios. Unlike race ways, high fish densities safely maintained. The intensive tank culture often proposed to achieve the more efficient use of water and promote maximum production though recirculation systems are expensive and limited. 


\section{LITERATURE CITED}

ACOSTA B.O. and GUPTA M.V. 2005. The status of introduced carp species in Asia. In Carp genetic resources for aquaculture in Asia (Eds) D.J. PENMAN, M.V. GUPTA, M.M. DEV, The World Fish Center, Penang. Malaysia. 121-128 pp.

DAVIS C.H., BHUIYAN A.R. and AMEN M. 1983. Fish production in managed farmers ponds with different feeding and stocking model. Proc. $4^{\text {th }}$ Seminar, Maximum Livestock production from Minimum Land. BAU, Mymensingh. 111-129 pp.

DEY M.M., RAB M.A., PARAGUAS F.J., PIUMSOMBUM S, RAMACHANDRA B, ALAM M.F. and MAHFUZUDDIN A. 2005. Fish consumption and food security: A disaggregated analysis by types of fish and classes of consumers in selected Asian countries. Aquac. Econ. Manage. 9(1/2). $89-111$.

GOMEZ K.A. and A.A. GOMEZ. 1985. Statistical Procedures for Agricultural Research (2 $2^{\text {nd }}$ ed.). John Wiley and Sons, New York. 680 p.

HUSSEIN M.S. 2012. Effect of feed, manure and their combination on the growth of Cyprinus carpio fry and fingerlings Egypt. J. Aquat. Biol. Fish. 16(2): 153-168.

JHINGRAN V.G. 1982. Fish and fisheries of India. Hindustan Publishing Co. New Delhi. 394-450 pp.

LARMOYENUX J.D., PIPER R.G. and CHENOWETH. 1973. Evaluation of circular tanks for salmonid production. Progressive Fish-Culturist 35:122-131.

LI S.F. and MATHIAS J (Editors). 1994. Fresh Water Fish Culture in China: Principles and Practices. Elsevier, Amsterdam.

SHRESTHA M.K. 1999. Summer and winter growth of grass carp (Ctenopharyngodon idella) in a polyculture fed with napier grass (Pennisetum purpureum) in the subtropical climate of Nepal. J. Aqua. Trop. 14 (1): 57-64.

YANG H.Z., FANG Y.X., and LIU Z.Y. 1990. The biological effects of grass carp (Ctenopharyngodon idella) on filter-feeding and omnivorous fish in polyculture. In: R. Hirano and I. Hanyu (Eds), The Second Asian Fisheries Forum. Asian Fisheries Society, Manila, Philippines. 197-200 pp. 